\title{
Growth rates of natural tintinnid populations in Narragansett Bay
}

\author{
Peter G. Verity \\ Graduate School of Oceanography, University of Rhode Island, Kingston, Rhode Island 02882, USA
}

\begin{abstract}
Natural microzooplankton populations were pre-screened through $202 \mu \mathrm{m}$ mesh to remove larger predators and incubated in situ for $24 \mathrm{~h}$ in lower Narragansett Bay. Growth rates of tintinnid ciliates were calculated from changes in abundance; experiments were conducted at weekly intervals for 2 yr. Growth rates ranged from 0 to 3.3 doublings $d^{-1}$; annual minima and maxima in growth rates occurred during the summer. Temperature regulated maximum species growth rates, while net community growth rates were primarily influenced by food quality and availability. Growth rates were depressed during blooms of small, solitary centric diatoms (Thalassiosira) and the antagonistic flagellate Olisthodiscus luteus, in agreement with previous laboratory studies. Excluding experiments when these phytoplankton were abundant, tintinnid growth rates increased asymptotically with nanoplankton $(<10 \mu \mathrm{m}$ and $<5 \mu \mathrm{m})$ biomass and production rates. Smaller tintinnid species showed higher maximum growth rates. Nine species exhibited maximum growth rates which equalled or exceeded 2.0 doublings $\mathrm{d}^{-1}$, and 11 other species exceeded 1.0 doubling $d^{-1}$. Their high abundance and rapid growth suggest that tintinnids were important grazers of nanoplankton and rapidly entered food webs in Narragansett Bay.
\end{abstract}

\section{INTRODUCTION}

One of the major problems in plankton ecology is estimation of growth rates and secondary production of zooplankton. Numerous techniques have been proposed to deal with the problem of continuously breeding populations, the most common being application of laboratory-derived growth rate data to population estimates (Uye et al. 1983), the population dynamics method (Durbin \& Durbin 1981), and the use of such physiological measures as production/biomass (P/B) ratios (Tremblay \& Roff 1983). Each approach is limited by the validity of inherent assumptions and the accuracy of basic growth variables and demographic statistics (Edmondson 1974, Andrew 1983). Large volume containment studies (Beers et al. 1977) eliminate many census problems, but are expensive and labor-intensive. The percentage of dividing cells has been proposed as an index of population reproduction rate of unicellular microplankton (Coats \& Heinbokel 1982). However, derivation of growth rates of natural populations requires knowledge of the duration of recognizable division stages for each species, which may vary with biotic and abiotic factors. Dialysis and polycarbonate membrane cage cultures, which contain micro- plankton populations while permitting water exchange with the environment, obviate these problems and have been used successfully to measure grazing and growth rates of natural microzooplankton populations under in situ conditions (Stoecker et al. 1983, Verity 1986).

Tintinnids are the dominant ciliate microzooplankton in lower Narragansett Bay (Verity 1984). They are sufficiently abundant that small volume containers incubated in situ can be used to investigate population dynamics in the presence of their natural food supply. The present study reports on growth rates of natural populations incubated in situ for $24 \mathrm{~h}$ at weekly intervals over a 2 yr period, and describes the functional response of growth rates to variations in temperature and phytoplankton abundance and species composition.

\section{METHODS}

Experiments were conducted in lower Narragansett Bay, Rhode Island $\left(41^{\circ} 30^{\prime} \mathrm{N} ; 71^{\circ} 23^{\prime} \mathrm{W}\right)$ at ca weekly intervals $(\mathrm{n}=88$ ) from May 1981 to July 1983. Natural microzooplankton communities were collected by filling a $20 \mathrm{l}$ plastic bucket fitted with a $202 \mu \mathrm{m}$ Nitex 
mesh across the mouth to exclude larger predators. Three $2 \mathrm{l}$ dialysis bags $(90 \mathrm{~mm}$ inflated diameter, 12,000 MW cutoff), which had been autoclaved and rinsed in distilled water to remove glycerin, were filled with the $<202 \mu \mathrm{m}$ plankton communities and attached to a mooring line at a depth of $1 \mathrm{~m}$. Sample collection and filling of dialysis bags was conducted at the experimental site, located $50 \mathrm{~m}$ offshore in $7 \mathrm{~m}$ of water. The entire process took $20 \mathrm{~min}$, and the bags were left in situ for $24 \mathrm{~h}$. Incubations generally began between 1000 and $1200 \mathrm{~h}$ as preliminary experiments indicated no diel differences in tintinnid growth rates, in agreement with previous investigations (Heinbokel 1978b, Coats \& Heinbokel 1982).

Chlorophyll a (chl a) and particulate organic carbon (POC) in the $<153 \mu \mathrm{m},<10 \mu \mathrm{m}$, and $<5 \mu \mathrm{m}$ size fractions, and tintinnid abundance were measured on subsamples from the initial community; final tintinnid abundance in each of the 3 bags was determined after $24 \mathrm{~h}$. Samples were filtered onto Gelman A/E $0.45 \mu \mathrm{m}$ glass fiber filters. Chl a was extracted in $90 \%$ acetone by grinding and measured in triplicate before and after acidification using the fluorometric method of HolmHansen et al. (1965). POC was determined in duplicate on a Hewlett Packard 185B CHN analyzer (Sharp 1974). The mean coefficient of variation of triplicate chl a measurements on population subsamples was $\pm 4 \%$, and the range of duplicate POC measurements was $\pm 8 \%$ of the mean.

One 1 from the initial bucket sample and 11 from each of the 3 dialysis bags after $24 \mathrm{~h}$ were preserved in seawater-buffered formalin and concentrated by settling to a final volume of 5 to $10 \mathrm{ml}$. A minimum of 3 replicate $1 \mathrm{ml}$ counts in Sedgwick Rafter chambers from the initial and each of the 3 final 5 to $10 \mathrm{ml}$ concentrates assessed initial and final tintinnid abundances; entire samples were enumerated during periods of low abundance. Identification (Table 1) was based on lorica morphology after Kofoid \& Campbell (1929, 1939). Tintinnid growth rates (doublings $\mathrm{d}^{-1}$ ) were calculated for each dialysis bag, assuming exponential growth (Verity \& Stoecker 1982), from:

$$
K=(1 / t) \log _{2}\left(N_{t} / N_{0}\right)
$$

where $\mathrm{N}_{\mathrm{t}}$ and $\mathrm{N}_{0}=$ tintinnid numbers at Days 1 and 0 . Mean community growth rates $(\mathrm{K})$ represent the mean increase in abundance in the 3 dialysis bags of all species combined during the $24 \mathrm{~h}$ incubations. Maximum growth rates $\left(\mathrm{K}_{\mathrm{m}}\right)$ represent the maximum observed rate for an individual species averaged over the 3 dialysis bags within a given experiment. Species growth rates in Table 2 represent growth rates in experiments in which the final mean abundance of a given species exceeded $100 \mathrm{l}^{-1}$, as lower abundances generally had broad confidence intervals around mean estimates. The precision of triplicate Sedgwick-Rafter counts was $\pm 15 \%$ of the mean. This uncertainty was equivalent to a maximum error of 0.2 doublings $\mathrm{d}^{-1}$. Zero growth indicated that abundance did not increase during a given experiment; declines in abundance significantly $(p<0.05)$ greater than counting errors were not observed.

Correlations between rate and biomass parameters were analyzed using functional (geometric mean) regressions as both dependent and independent variables were subject to measurement error (Ricker 1973, Laws \& Archie 1981). All statistical tests were performed according to Snedecor \& Cochran (1967). Temperature dependence $(\mathrm{T})$ of growth rate $(\mathrm{K})$ was analyzed using $K=e^{x(T)} \cdot Q_{10}$ was defined as $e^{10(x)}$.

\section{RESULTS}

Twenty-six tintinnid species representing 9 genera were enumerated (Table 1). The genus Tintinnopsis contributed the most species (11), followed by Stenosemella (3) and Eutintinnus (2). Three Tintinnopsis species exhibited the highest abundance maxima:

Table 1. Tintinnid species and their maximum abundance (C) $\left(\times 10^{3} \mathrm{l}^{-1}\right)$ in the dialysis bags

\begin{tabular}{lr} 
& \\
Species & $\mathrm{C}$ \\
\hline Eutintinnus pectinis (Kofoid \& Campbell) & \\
$\quad$ (= Tintinnus pectinis of Hargraves 1981) & 0.7 \\
Eutintinnus sp. (= Tintinnus sp. of Hargraves 1981) & 2.7 \\
Favella sp. (see Verity \& Stoecker 1982) & 0.3 \\
Helicostomella subulata (Ehrenberg) Jorgensen & 3.5 \\
Metacylis annulifera (Ostenfeld \& Schmidt) & 2.0 \\
Parafavella sp. (see Davis 1978) & 0.1 \\
Stenosemella oliva (Meunier) & 4.0 \\
Stenosemella steini (Jorgensen) & 1.7 \\
Stenosemella ventricosa & 0.6 \\
$\quad$ (Clap. \& Lachm.) Jorgensen & \\
Stylicauda platensis & 0.1 \\
(Cunha \& Fonseca) (see Cosper 1972) & \\
Tintinnidium fluviatile (Stein) Kent & 1.1 \\
Tintinnopsis acuminata Daday & 9.6 \\
Tintinnopsis baltica Brandt & 1.1 \\
Tintinnopsis beroidea Stein & 1.7 \\
Tintinnopsis dadayi Kofoid & 0.1 \\
Tintinnopsis kofoidi Hada & 0.5 \\
Tintinnopsis levigata (Kofoid \& Campbell) & 0.4 \\
Tintinnopsis minuta Wailes & 70.0 \\
Tintinnopsis nucula (Fol) Brandt & 0.1 \\
Tintinnopsis parva Merkle & 1.2 \\
Tintinnopsis rapa Meunier & 3.0 \\
Tintinnopsis tubulosoides Meunier & 0.5 \\
Tintinnopsis undella Meunier & 0.2 \\
Tintinnopsis urnula Meunier & 0.2 \\
Tintinnopsis vasculum Meunier & 5.0 \\
Tintinnopsis ventricosoides Meunier & 1.0 \\
& \\
&
\end{tabular}


T. minuta $\left(70.0 \times 10^{3} \mathrm{l}^{-1}\right), T$. acuminata $\left(9.6 \times 10^{3}\right)$, and $T$. vasculum $\left(5.0 \times 10^{3}\right)$. A total of 14 of 26 species showed maximum abundances exceeding $10^{3}$ tintinnids $1^{-1}$. Species number in a given experiment ranged from 2 to 15, and was highest during latesummer and earlyfall (Fig. 1). The lowest number of tintinnid species generally occurred during late fall and winter. Tintinnid community growth rates ranged from 1.9 to 2.4 doublings $\mathrm{d}^{-1}$ during the summer of 1981 , and then declined to 0.3 doublings $\mathrm{d}^{-1}$ during October. Growth rates fluctuated between 0.2 and 1.0 doublings $\mathrm{d}^{-1}$ during the winter, with no growth observed in late March. Growth rates increased during the spring and exhibited rapid fluctuations during the summer, with an extensive depression in late June and early July. Community growth rates rebounded to the $2 \mathrm{yr}$ maximum of 3.2 doublings $\mathrm{d}^{-1}$ in early August, and then declined gradually through the fall. Low growth rates were observed during the winter of 1982-1983; gradual increases in the spring led to a June peak of 2.8 doublings $\mathrm{d}^{-1}$. The mean tintinnid community growth rate over the 2 yr period was 0.8 doublings $\mathrm{d}^{-1}$.

The maximum observed growth rate for an individual species within each experiment generally followed patterns in community growth rate (Fig. 1). The maximum growth rate ranged from 0.1 doublings $d^{-1}$ during the mid-summer growth minimum to 3.3 doublings $\mathrm{d}^{-1}$ by Tintinnopsis minuta in early August 1982 . T. minuta was usually the fastest growing species in the summer and fall; T. rapa, Stenosemella oliva, and $S$. steini were the most rapid growers in the late fall and winter. Nine species exhibited maximum growth rates equal to, or greater than, 2.0 doublings $\mathrm{d}^{-1} ; 11$ others exceeded 1.0 doublings $\mathrm{d}^{-1}$ (Table 2). T. minuta exhibited growth rates exceeding 3.0 doublings $d^{-1}$ in 3 experiments, and greater than 2.0 doublings $\mathrm{d}^{-1}$ in 7 additional experiments. Growth of $T$. acuminata exceeded 1.0 and 2.0 doublings $d^{-1}$ in 12 and 4 of 23 experiments, respectively. T. minuta, Eutintinnus pectinis, and Eutintinnus sp. grew at an average rate of 1.7 to 1.8 doublings $\mathrm{d}^{-1}$ in all experiments in which they were present. Three common species, $T$. acuminata, $T$. fluviatile, and $T$. baltica, grew at mean rates of 0.9 to 1.1 doublings $\mathrm{d}^{-1} ; 4$ rare species (Favella sp., $T$. beroidea, T. dadayi, and T. kofoidl) averaged 1 to 2 doublings $\mathrm{d}^{-1}$.

$\mathrm{Chl} a$ in the $<153 \mu \mathrm{m}$ fraction was 4 to $5 \mu \mathrm{g} \mathrm{l}^{-1}$ during the summer of 1981 (Fig. 2), due primarily to the dinoflagellates Katodinium rotundatum, Prorocentrum minimum, $P$. triestinum, and several uncharacterized microflagellates; most of these passed a $10 \mu \mathrm{m}$ mesh. A short bloom of Thalassiosira rotula occurred in early October, followed by a more extensive development of $T$. constricta during December; both species exceeded $10 \mu \mathrm{m}$ in effective valve diameter. Skeletonema costatum, Detonula confervacea, and Thalassiosira decipiens formed the annual winter-spring bloom during February-March 1982. Chl a in all size fractions remained low until mid-May, after which a series of blooms by Olisthodiscus luteus, Prorocentrum species, and several uncharacterized microflagellates dominated summer phytoplankton communities. The annual peak in nanoplankton standing stock occurred in early August, with chl a levels of 8.9 and $6.2 \mu \mathrm{g} \mathrm{l} \mathrm{l}^{-1}$ in the $<10 \mu \mathrm{m}$ and $<5 \mu \mathrm{m}$ size fractions, respectively. Chain-forming diatoms, primarily $S$. costatum and Asterionella glacialis, were abundant during early fall, peaking at $14.2 \mu \mathrm{g} \mathrm{chl} \mathrm{al^{-1 }}$ in the $<153 \mu \mathrm{m}$ fraction in early October. An extensive bloom of small, solitary Thalassiosira species, primarily $T$. constricta, occurred during November and December; unlike 1981, most of these passed a $10 \mu \mathrm{m}$ mesh but were retained by $5 \mu \mathrm{m}$ netting. $T$. constricta bloomed again in January 1983 and several microflagellate species were abundant in March. Small, solitary Thalassiosira species which passed $10 \mu \mathrm{m}$ but not $5 \mu \mathrm{m}$ mesh were dominant in
Fig. 1. (A) Water temperature $(\longrightarrow$ and tintinnid species number (--) within the dialysis bags. (B) Maximum observed growth rate for an individual species $(-)$ and community growth rate (---) for each experiment

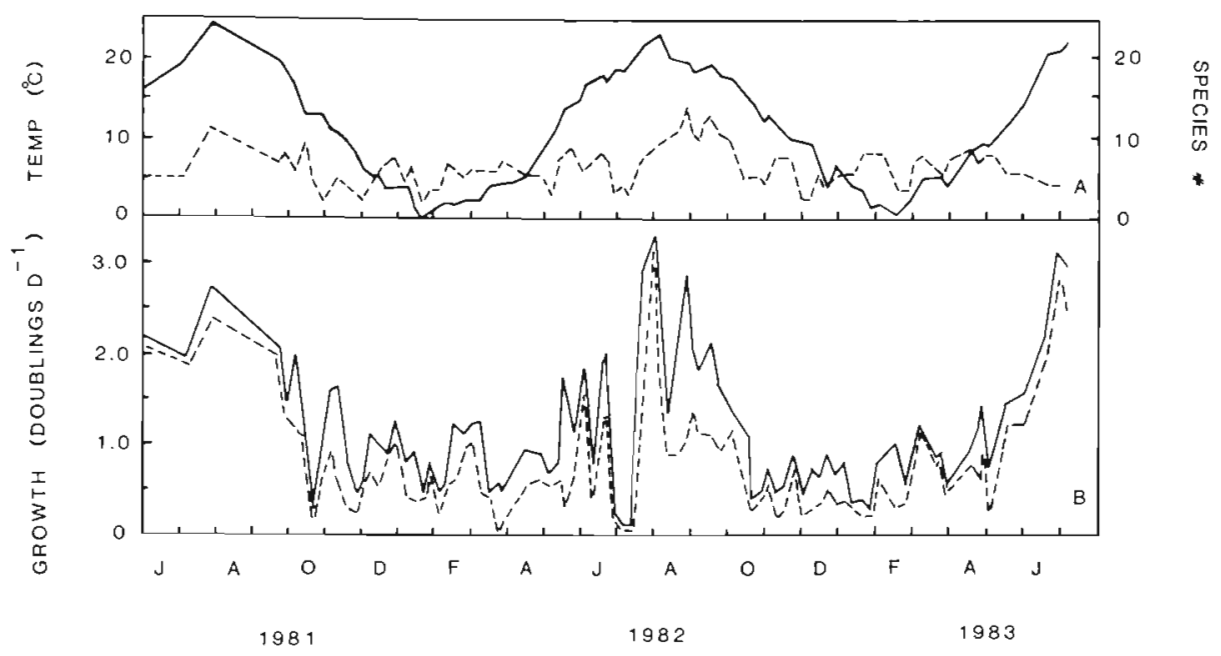


Table 2. Mean $(\mathrm{K})$, maximum $\left(\mathrm{K}_{\mathrm{m}}\right)$, and range of growth rates of various tintinnid species in those experiments where the final abundance of each species exceeded $1001^{-1} \cdot n_{t}=$ total number of experiments in which each species occurred; $n_{1}=$ number of experiments where growth was equal to or exceeded 1 doubling $\mathrm{d}^{-1} ; \mathrm{n}_{2}=$ number of experiments where growth was equal to or exceeded 2 doublings $d^{-1}$

\begin{tabular}{|c|c|c|c|c|c|c|}
\hline Species & $\mathrm{n}_{\mathrm{i}}$ & $\mathrm{n}_{1}$ & $\mathrm{n}_{2}$ & $\mathrm{~K}$ & Range & $\mathrm{K}_{\mathrm{m}}$ \\
\hline Eutintinnus pectinis & 2 & 2 & 1 & 1.7 & $(1.2-2.2)$ & 2.2 \\
\hline Eutintinnus sp. & 5 & 4 & 2 & 1.7 & $(0.8-2.2)$ & 2.2 \\
\hline Favella sp. & 1 & 1 & - & 1.3 & - & 1.3 \\
\hline Helicostomella subulata & 10 & 3 & 1 & 0.7 & $(0.0-2.0)$ & 2.0 \\
\hline Metacylis annulifera & 3 & 1 & 1 & 0.7 & $(0.0-2.0)$ & 2.0 \\
\hline Stenosemella oliva & 22 & 3 & 1 & 0.7 & $(0.2-2.2)$ & 2.2 \\
\hline Stenosemella steini & 20 & 2 & - & 0.5 & $(0.0-1.9)$ & 1.9 \\
\hline Stenosemella ventricosa & 2 & - & - & 0.4 & $(0.4-0.5)$ & 0.5 \\
\hline Tintinnidium fluviatile & 18 & 11 & - & 1.0 & $(0.0-1.6)$ & 1.6 \\
\hline Tintinnopsis acuminata & 23 & 12 & 4 & 1.1 & $(0.0-2.7)$ & 2.7 \\
\hline Tintinnopsis baltica & 18 & 7 & 1 & 0.9 & $(0.2-2.0)$ & 2.0 \\
\hline Tintinnopsis beroidea & 2 & 1 & 1 & 1.5 & $(0.6-2.4)$ & 2.4 \\
\hline Tintinnopsis dadayi & 1 & 1 & - & 1.9 & - & 1.9 \\
\hline Tintinnopsis kofoidi & 3 & 1 & - & 1.0 & $(0.7-1.3)$ & 1.3 \\
\hline Tintinnopsis levigata & 1 & 1 & - & 1.4 & - & 1.4 \\
\hline Tintinnopsis minuta & 28 & 23 & 10 & 1.8 & $(0.3-3.3)$ & 3.3 \\
\hline Tintinnopsis parva & 21 & 4 & - & 0.7 & $(0.0-1.2)$ & 1.2 \\
\hline Tintinnopsis rapa & 36 & 5 & - & 0.5 & $(0.0-1.3)$ & 1.3 \\
\hline Tintinnopsis tubulosoides & 5 & 1 & - & 0.8 & $(0.0-1.9)$ & 1.9 \\
\hline Tintinnopsis undella & 3 & - & - & 0.6 & $(0.1-0.9)$ & 0.9 \\
\hline Tintinnopsis vasculum & 14 & 3 & - & 0.8 & $(0.2-1.5)$ & 1.5 \\
\hline Tintinnopsis ventricosoides & 2 & 1 & - & 0.5 & $(0.1-1.0)$ & 1.0 \\
\hline
\end{tabular}

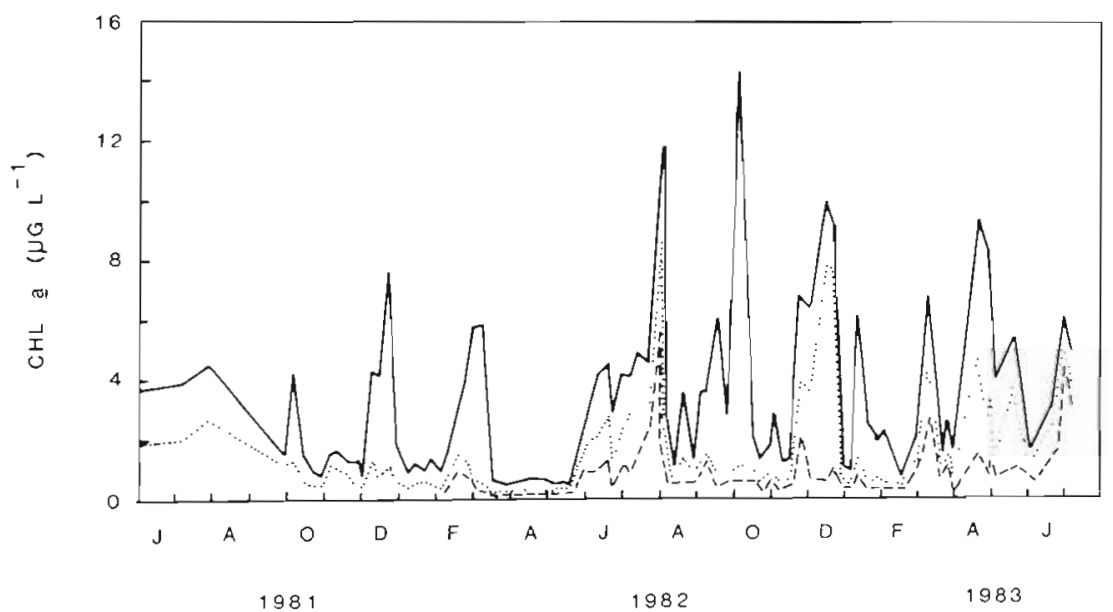

Fig. 2. Chl $a$ in the $<153 \mu \mathrm{m}(-)$ $<10 \mu \mathrm{m}(\quad \cdots)$, and $<5 \mu \mathrm{m}(---)$ size fractions within the dialysis bags
mid-April and mid-May, along with Rhizosolenia species, predominantly $R$. delicatula. Several small Gymnodinium and microflagellate species bloomed during June and early July. The $2 \mathrm{yr}$ mean $<153 \mu \mathrm{m}$ chl a concentration was $3.3 \mu^{-1} \mathrm{l}^{-1}$ (range: 0.5 to 14.2 ); chl a passing $10 \mu \mathrm{m}$ and $5 \mu \mathrm{m}$ meshes averaged $49 \%$ $(n=88)$ and $29 \%(n=68)$, respectively. Particulate organic carbon (POC) generally followed changes in chl a, particularly in the smaller size fractions (Fig. 3). The 2 yr mean $<153 \mu \mathrm{m}$ POC concentration was 555 $\mu \mathrm{gC} \mathrm{l}^{-1}$ (range: 221 to $1312 ; \mathrm{n}=82$ ); POC passing $10 \mu \mathrm{m}$ and $5 \mu \mathrm{m}$ meshes averages $49 \%(n=82)$ and $29 \%(n=65)$, respectively. Geometric mean regression yielded:

$<5 \mu \mathrm{mPOC}=79+155(<5 \mu \mathrm{mchl} a), \mathrm{r}^{2}=0.86$, $\mathrm{p}<0.05$

$<10 \mu \mathrm{m}$ POC $=145+100(<10 \mu \mathrm{m} \mathrm{chl} \mathrm{a}), \mathrm{r}^{2}=0.64$,

$\mathrm{p}<0.05$;

$<153 \mu \mathrm{m}$ POC $=286+78(<153 \mu \mathrm{mchl} a), \mathrm{r}^{2}=0.26$, $\mathrm{p}<0.05$. 
Fig. 3. Particulate organic carbon (POC) within the dialysis bags. Symbols as in

Fig. 2

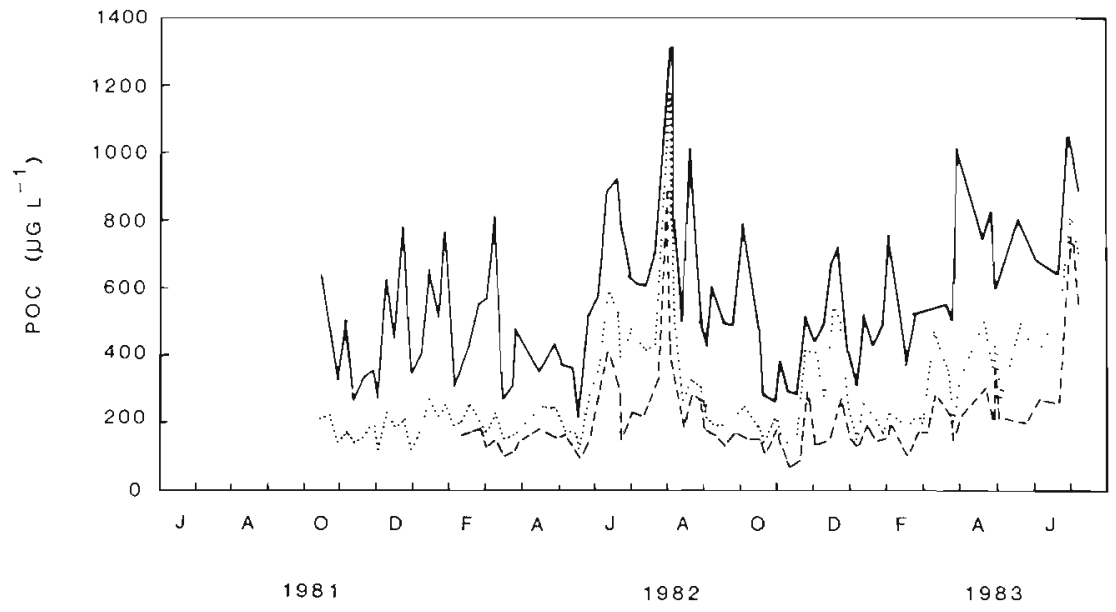

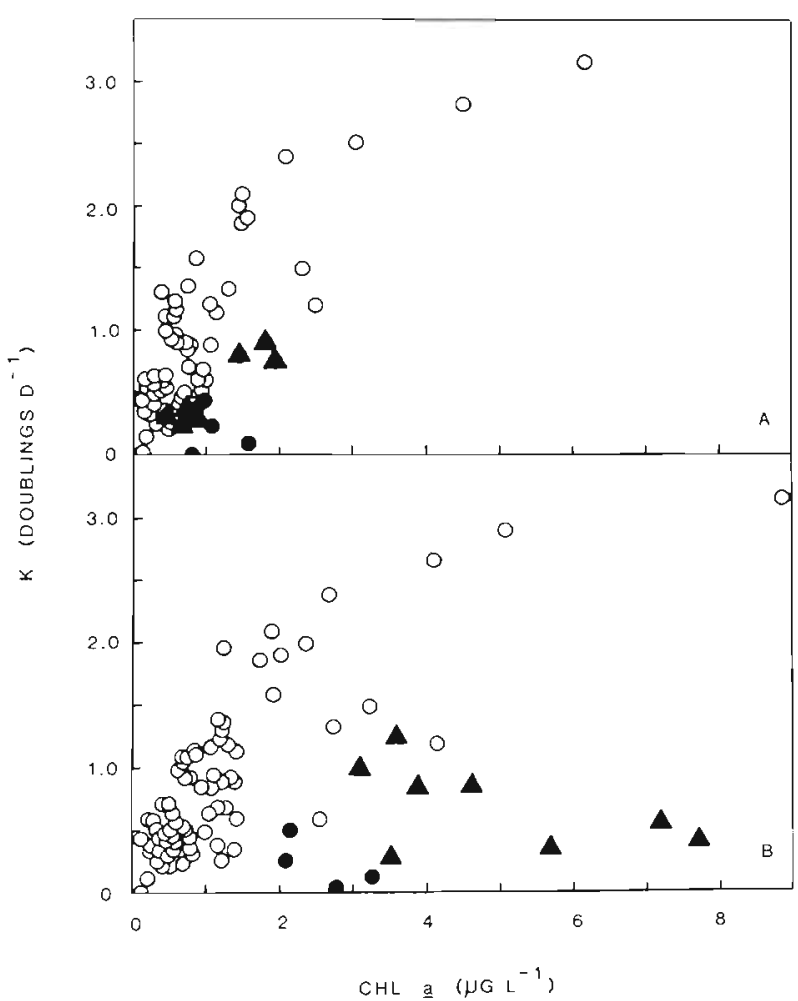

Fig. 4. Community growth rates as a function of chl $a$ in the (A) $<5 \mu \mathrm{m}$ and (B) $<10 \mu \mathrm{m}$ size fractions. Filled circles are experiments in which Olisthodiscus luteus exceeded $10^{3}$ cells $\mathrm{ml}^{-1}$. Filled triangles represent experiments during blooms of solitary Thalassiosira species which passed a $10 \mu \mathrm{m}$ mesh

Community growth rates increased with chl $a$ (Fig. 4) and POC (Fig. 5) in the $<10 \mu \mathrm{m}$ and $<5 \mu \mathrm{m}$ size fractions. Tintinnid growth rates during blooms of Olisthodiscus and Thalassiosira were low considering the standing stock of nanoplankton in the $<10 \mu \mathrm{m}$ fraction (see 'Discussion'). Excluding these experiments, community growth increased with chl a and POC concentration over the ranges observed in Nar-

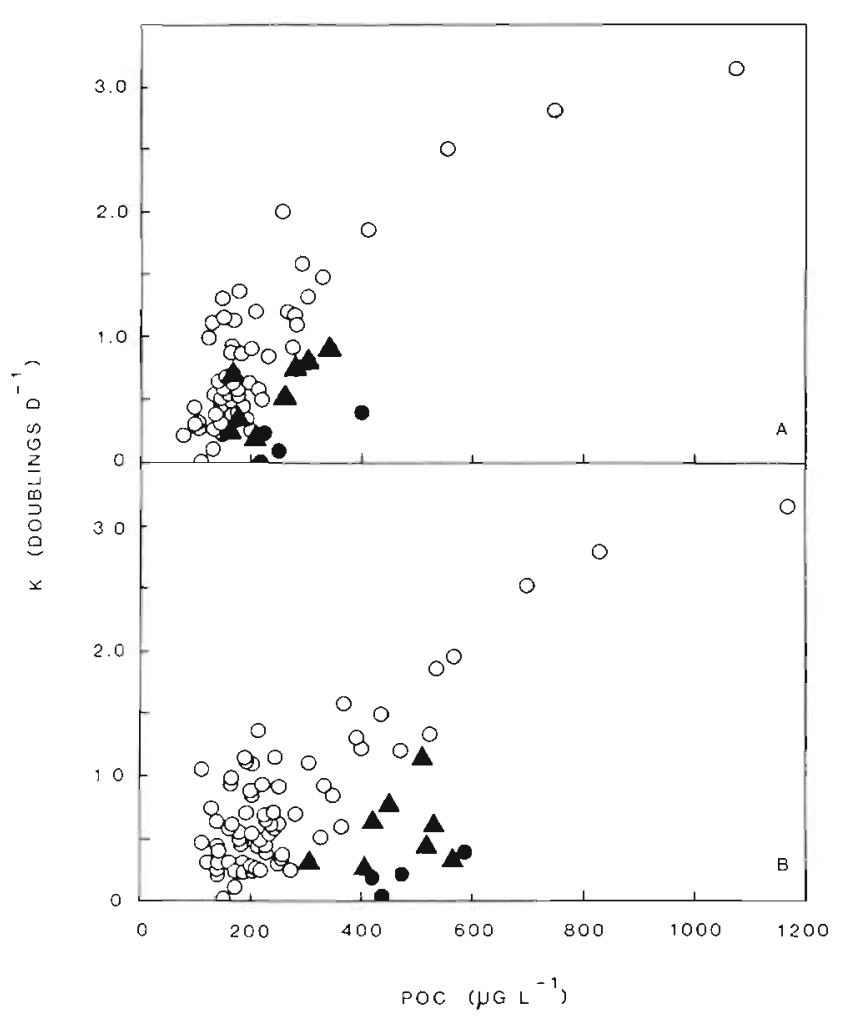

Fig. 5. Community growth rates as a function of particulate organic carbon (POC) in the $(A)<5 \mu \mathrm{m}$ and $(B)<10 \mu \mathrm{m}$ size fractions. Symbols as in Fig. 4

ragansett Bay. The maximum growth rate observed for a given species in each experiment also increased with chl a (Fig. 6) and POC (data not shown). Maximum growth rates saturated at 1 to $3 \mu \mathrm{g} \mathrm{chl} a(<5 \mu \mathrm{m})$ and 2 to $4 \mu \mathrm{g} \operatorname{chl}$ a $(<10 \mu \mathrm{m})$, and were depressed during blooms of Olisthodiscus and Thalassiosira.

Tintinnid community and maximum observed species growth rates increased rapidly with temperature above 8 to $10^{\circ} \mathrm{C}$, although considerable variability 


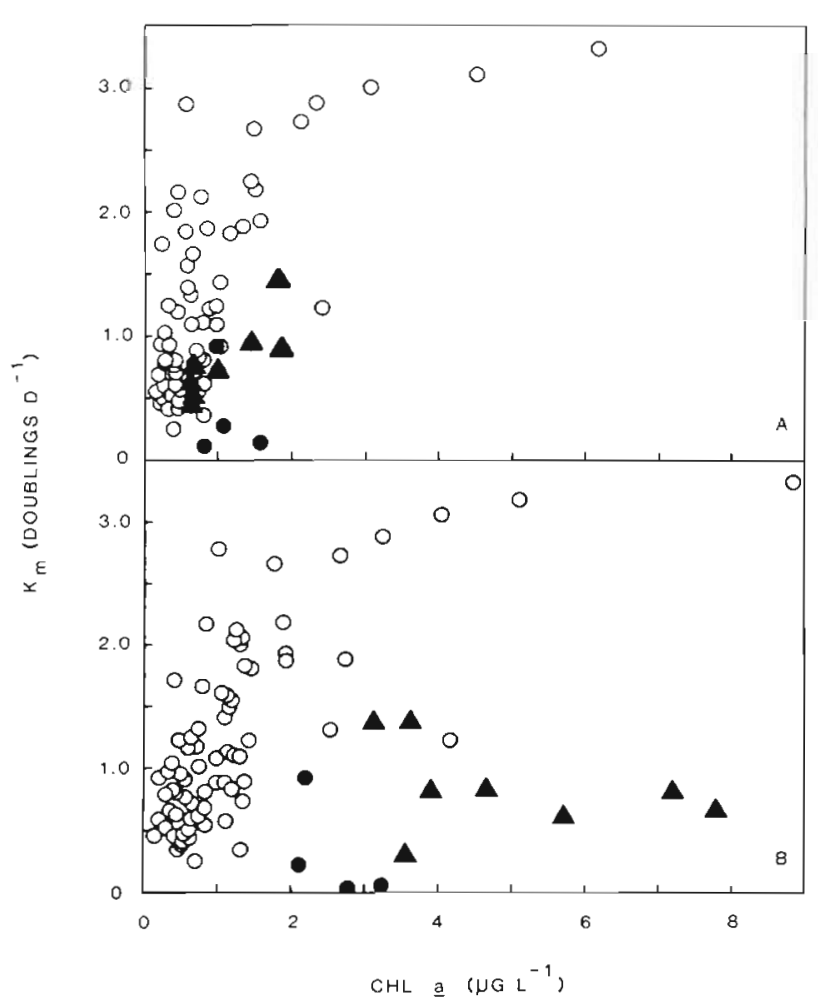

Fig. 6. Maximum growth rate observed for an individual species within a given experiment as a function of chl $a$ in the (A) $<5 \mu \mathrm{m}$ and (B) $<10 \mu \mathrm{m}$ size fractions. Symbols as in Fig. 4

in growth was observed at a given temperature (Fig. 7). The dates coinciding with Olisthodiscus blooms clearly showed depressed growth. Fitting the logtransformed data, with the exception of high Olisthodiscus experiments, to an exponential yielded:

$$
\mathrm{K}=0.55 \mathrm{e}^{0.06(\mathrm{~T})}, \mathrm{r}^{2}=0.49, \mathrm{n}=84 .
$$

Selecting the highest growth rate at each temperature yielded:

$$
\mathrm{K}^{\prime}=0.71 \mathrm{e}^{0.06(\mathrm{~T})}, \mathrm{r}^{2}=0.81, \mathrm{n}=26 .
$$

Both exponents are equivalent to a $\mathrm{Q}_{10}$ of 1.8 .

Stepwise regression analyses were performed on both the community growth and maximum observed species growth rate data to resolve the interactive effects of temperature and food concentration. Excluding Olisthodiscus and Thalassiosira blooms, chl a accounted for the largest source of variance in community growth rates: $<10 \mu \mathrm{m}$ chl $a$ explained $60 \%$ of the variance compared to $14 \%$ by temperature $;<5 \mu \mathrm{m}$ chl a explained $68 \%$ compared to $12 \%$ due to temperature. However, the largest fraction of variance in maximum growth rate was attributed to temperature: $58 \%$ of the explained variance compared to $<10 \mu \mathrm{m}$ chl a $(12 \%)$, and $63 \%$ compared to $<5 \mu \mathrm{m}$ chl a $(12 \%)$.

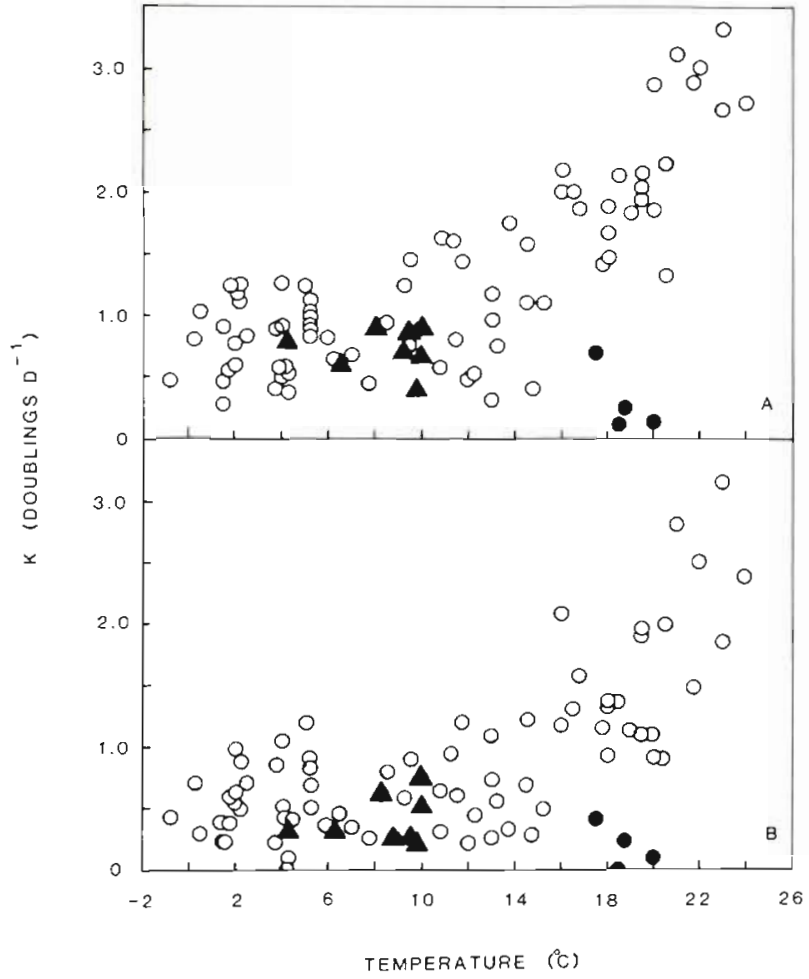

Fig. 7. Tintinnid growth rates as a function of temperature. (A) Maximum observed growth rate for an individual species in each experiment. (B) Community growth rate. Symbols as in Fig. 4

\section{DISCUSSION}

The most abundant tintinnids were summer dominants (Tintinnopsis minuta, $T$. acuminata) or yearround species whose abundance maxima occurred during the summer ( $T$. vasculum). Species composition and abundance within the dialysis bags was similar to that observed over a 3 yr period at another site in lower Narragansett Bay (Verity 1984). Tintinnid community growth rates ranged from 0 to 3.2 doublings $\mathrm{d}^{-1}$, with the fastest growth rates during the late spring, summer, and early fall; slower growth characterized late fall and winter populations. A dramatic decline in growth coincided with summer blomms of Olisthodiscus Iuteus, a photosynthetic flagellate inhibitory to tintinnid growth at low concentrations and toxic at bloom levels (Verity \& Stoecker 1982). O. Iuteus exceeded $10^{3}$ cells $\mathrm{ml}^{-1}$ in the dialysis bags on 4 dates in 1982: June 10 (3160 cells ml $\left.{ }^{-1}\right)$, June 28 (2900), July $6(2500)$, and July 12 (1940). Respective community growth rates were $0.4,0.2,0.0$, and 0.1 doublings $\mathrm{d}^{-1}$, despite warm temperatures. This suggests that the inverse relation between tintinnid abundance and $O$. luteus concentration (Verity \& Stoecker 1982) was due to inhibition of in situ growth rates. 
Growth rates were compared to the $<10 \mu \mathrm{m}$ and $<5 \mu \mathrm{m}$ size fractions because the maximum particle size ingested by tintinnids is 40 to $45 \%$ of the oral lorica diameter (Spittler 1973, Heinbokel 1978b), and the mean oral lorica diameter of Narragansett Bay tintinnids is 26 to $28 \mu \mathrm{m}$ (Verity 1984). Growth rates increased rapidly with increasing chl $a$ in the $<5 \mu \mathrm{m}$ size class, with an asymptotic response at elevated chl a levels. However, high chl a levels in the $<10 \mu \mathrm{m}$ fraction were not always associated with rapid tintinnid growth rates because the dominant phytoplankton during these events were Olisthodiscus and small Thalassiosira species which passed a $10 \mu \mathrm{m}$ mesh but not $5 \mu \mathrm{m}$ netting. Thalassiosira is an unsuitable food for coastal tintinnids due to the presence of extruded threads which impede or prevent ingestion (Verity \& Villareal 1985). Excluding these dates, growth rates showed an asymptotic response to $<10 \mu \mathrm{m}$ chl a like that observed for $<5 \mu \mathrm{m}$ chl a. A similar functional relation was observed between growth and POC concentration, but saturation of growth at the highest POC levels was not observed, reflecting the higher C:chl a ratio in smaller size classes of particulate matter. The increasing $\mathrm{C}$ :chl a ratios in smaller size fractions suggest a greater detrital component or higher C:chl a ratios in phytoplankton in these small size groups. The $C: c h l$ a ratios in the present study agree with the range calculated by Durbin et al. (1975) for Narragansett Bay phytoplankton over an annual cycle.

Daily chl $a$ production in the $<10 \mu \mathrm{m}$ and $<5 \mu \mathrm{m}$ fractions in the absence of $>10 \mu \mathrm{m}$ grazers was determined concurrently with tintinnid growth rates in 52 consecutive weekly experiments (Verity 1986). A highly significant linear relation between production and biomass occurred over an annual cycle in Narragansett Bay. Tintinnid growth rates (Fig. 8). increased with chl a production in both size classes, indicating that conditions favorable for the growth of most phototrophic nanoplankton enhanced growth of their predators. Food quality is also clearly important, as rapidly growing Olisthodiscus and Thalassiosira populations suppressed tintinnid reproduction.

Growth rates of tintinnids in laboratory culture (Heinbokel 1978a, Verity 1985) showed an asymptotic response to phytoplankton carbon concentration similar to that observed for chl a in Narragansett Bay. Maximum growth rates in culture occurred at phytoplankton concentrations close to those at which growth rates of field populations saturated, using a phytoplankton C:chl a of 25 (Parsons \& Takahashi 1973) to convert in situ chl a levels to phytoplankton carbon equivalents. The high phytoplankton concentrations at which depressed growth rates were found in laboratory studies exceeded those measured in the field, suggesting that tintinnids in lower Narragansett Bay were not

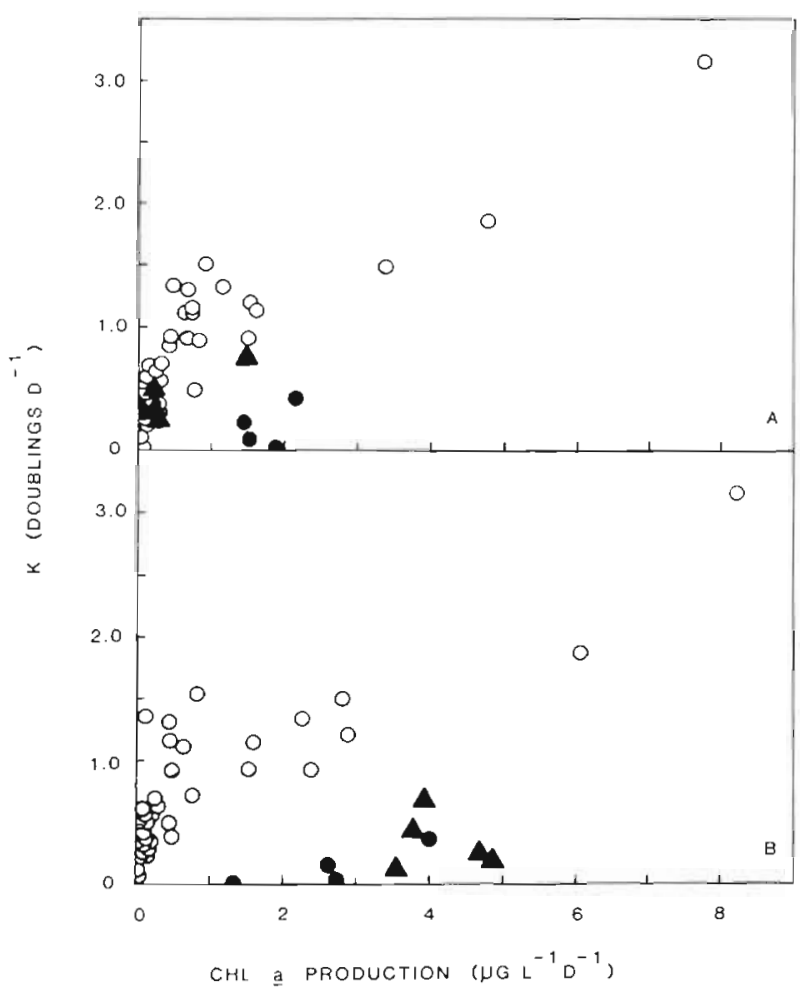

Fig. 8. Community growth rates as a function of chl a production rates in the $(A)<5 \mu \mathrm{m}$ and $(B)<10 \mu \mathrm{m}$ size fractions.

Production rates from Verity (1986). Symbols as in Fig. 4

inhibited by high nanoplankton abundance. The data in Fig. 1 indicate that low food availability was a more important factor, as $K_{m}$ consistently exceeded $K$. The ratio $\mathrm{K}: \mathrm{K}_{\mathrm{m}}$ was independent of temperature and nanoplankton chl a $(p<0.05)$, suggesting that speciesspecific differences in growth may reflect variations in food quality or prey preferences. Additional food sources were also available. Large tintinnid species may have utilized phytoplankton $>10 \mu \mathrm{m}$ in effective diameter. Apochlorotic flagellates were a potential food supply, although their importance in tintinnid diets is uncertain. Preliminary experiments indicated that Narragansett Bay tintinnids did not survive in culture on a diet of heterotrophic flagellates (Verity unpubl.), in agreement with previous studies (Blackbourn 1974). The extent to which zooflagellates are eaten by tintinnids, however, complicates interpretation of potential food limitation of natural tintinnid populations.

Early studies indicated that bacteria were not likely to be a significant food source for tintinnids (Spittler 1973). More recently, experiments using tritiated thymidine suggested that at least one tintinnid, Helicostomella subulata, can ingest bacteria at low rates (Hollibaugh et al. 1980). Narragansett Bay tintinnids did not survive in culture when fed bacteria ranging in 
concentration from $10^{4} \mathrm{ml}^{-1}$ to $10^{7} \mathrm{ml}^{-1}$ (Verity unpubl.), and the importance of bacteria in the diet of natural tintinnid populations is unknown. To the extent that tintinnid growth in Narragansett Bay was limited by abundance of nanoplankton, bacteria and detritus may have provided an additional nutrient source. In the present study, dialysis tubing composed of regenerated cellulose was autoclaved and rinsed to remove impregnated glycerin, which might otherwise serve as a substrate for bacterial growth. Scanning electron microscopy of the inside walls of dialysis tubes incubated for $1 \mathrm{~d}$ in Narragansett Bay exhibited little change from new tubing, with only an occasional bacterial cell present (Vargo et al. 1975). Thus, tintinnid populations within the dialysis bags were not likely to have used artificially elevated bacteria concentrations as a food supply. The importance of detritus in tintinnid diets is unknown. Conceivably, ingestion of detritus may be a prerequisite for or occur during lorica formation, especially in species thought to build their loricas in conjunction with the sediments (Gold \& Morales 1976). Further data are required to evaluate the importance to tintinnids of food other than phototrophic cells.

Tintinnid growth rates in Narragansett Bay increased with temperature at a rate equivalent to a $Q_{10}$ of 1.8 , in agreement with the temperature dependence of growth in culture (Stoecker at al. 1983, Verity 1985). Stepwise regression indicated that temperature was more important than chl a concentration in regulation of maximum in situ growth rates, which approximated those in culture (Heinbokel 1978a, Verity \& Stoecker 1982, Taniguchi \& Kawakami 1983, Verity 1985). However, community growth rates were less than maximal for much of the year and were more strongly affected by chl a than by temperature. Thus, the potential growth rate on a given date was set by temperature, and the realized rate of population increase varied with food quality and availability. In addition, body size influenced growth rates (Fig. 9). Smaller species exhibited higher maximum growth rates, in agreement with studies in laboratory culture of tintinnids (Heinbokel 1978a) and freshwater ciliates
(Finlay 1977). The exponent of the regression of $\log \mathrm{K}_{\mathrm{m}}$ on $\log C(-0.23)$ is similar to the general equation for unicellular organisms (-0.28: Fenchel 1974), but is significantly greater than the weak mass dependence of phytoplankton growth $(-0.13$ to -0.15 : Banse 1982).

The in situ growth rates represent net increases in abundance of natural tintinnid populations incubated in the presence of other $<202 \mu \mathrm{m}$ plankton. Screening with $202 \mu \mathrm{m}$ mesh excluded larger predators such as copepods from the dialysis bags. However, some ciliates such as Didinium are voracious predators and, although such camivores were rare, these net population increases should be considered as conservative measurements of actual growth rates. Large tintinnids such as Favella sp. (ca $70 \mu \mathrm{m}$ oral lorica diameter, $200 \mu \mathrm{m}$ length) were occasionally seen to contain small tintinnids such as Tintinnopsis minuta (ca $14 \mu \mathrm{m}$ oral diameter, $25 \mu \mathrm{m}$ length) and $T$. acuminata (ca $20 \mu \mathrm{m}$ oral diameter, $40 \mu \mathrm{m}$ length), in agreement with previous studies (Robertson 1983). However, such small species persistently demonstrated the most rapid growth rates, despite the potential for enhanced predation due to their small size.

Two physiological factors, conjugation and parasitism, occasionally influenced growth rates of selected species. Conjugation, or mating, which typically occurs prior to or after periods of rapid growth in culture (Stoecker et al. 1983, Verity unpubl.), was periodically observed in field populations. At times, as many as $20 \%$ of the individuals of a particular species, often Tintinnopsis minuta, T. acuminata, and Helicostomella subulata, were found in conjugation. In each case, mating was associated with low growth by that species. Parasitism of tintinnids by the dinoflagellate Duboscquella sp. was not as common in Narragansett Bay as in Perch Pond (Stoecker et al. 1983); occasional specimens of Favella sp., Eutintinnus pectinis, and Eutintinnus sp. were parasitized, especially during periods of declining tintinnid abundance.

Tintinnids are the numerically dominant ciliate microzooplankton in lower Narragansett Bay (Verity 1984). The present data demonstrated that individual

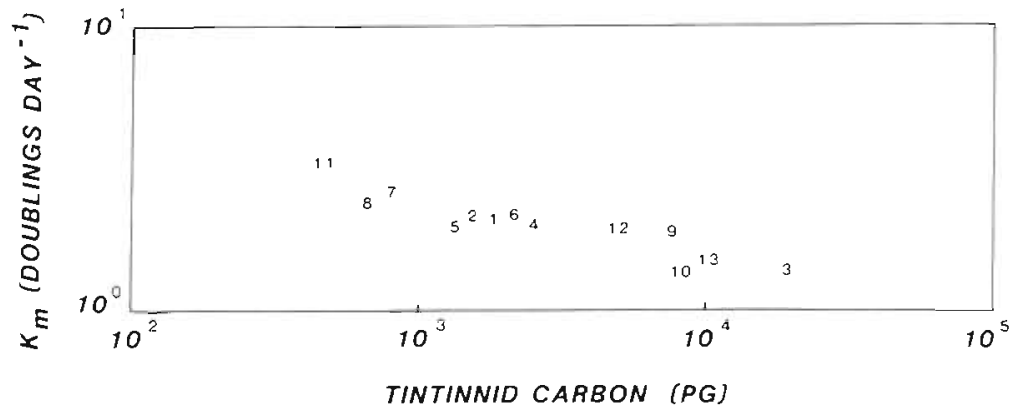

TINTINNID CARBON (PG)
Fig. 9. Maximum observed growth rates of individual species $\left(K_{m}\right)$ between 18 and $24^{\circ} \mathrm{C}$, as a function of tintinnid carbon content (C). Data on carbon content from Verity \& Langdon (1984). Geometric mean regression: $\log _{10} \mathrm{~K}_{\mathrm{m}}=1.10-$ $0.23\left(\log _{10} \mathrm{C}\right), \mathrm{r}^{2}=0.86 .1=$ Eutintinnus pectinis; $2=$ Eutintinnus sp.; $3=$ Favella sp.; $4=$ Helicostomella subulata; $5=$ Metacylis annulifera; $6=$ Stenosemella oliva; $7=$ Tintinnopsis acuminata; $8=T$. beroidea; $9=T$. dadayi $10=T$. kofoidi $11=T$. minuta $12=T$ tubulosoides: $13=T$, vasculum 
species grew in excess of 3 doublings $\mathrm{d}^{-1}$ in situ and that community growth rates exceeded 1 doubling $d^{-1}$ for ca 5 mo of the year. These data do not support the hypothesis (Banse 1982) that in situ growth rates of pelagic ciliates are low due to scarcity of suitably-sized food. Growth rates were similar in magnitude to and occasionally exceeded those of phototrophic nanoplankton in Narragansett Bay (Furnas 1982, Verity 1986), supporting the notion that ciliate intrinsic potentials are equivalent to those of their prey. Such high abundances and fast growth rates also suggest rapid entry into planktonic food webs: tintinnids may provide an important food source for larger omnivores, particularly during periods of low phytoplankton abundance (Robertson 1983, Stoecker \& Govoni 1984).

Acknowledgements. I thank C. Griswold and T. Villareal for assistance in sample collection. N. Hairston, Jr., P. E. Hargraves, S. Levings, J. McN. Sieburth, T. J. Smayda, D. Stoecker, and 2 anonymous referees offered constructive suggestions on various drafts of this manuscript. This work was supported by Department of Commerce (NOAA) Grant No. NA80RA-D00064 awarded to T. J. Smayda.

\section{LITERATURE CITED}

Andrew, T. E. (1983). The estimation of secondary production in a natural population of Daphnia hyalina (Leydig) using alternative methods of computation. Hydrobiologia 107: 3-18

Banse, K. (1982). Cell volumes, maximal growth rates of unicellular algae and ciliates, and the role of ciliates in the marine pelagial. Limnol. Oceanogr. 27: 1059-1071

Beers, J. R., Reeve, M. R., Grice, G. D. (1977). Controlled ecosystem pollution experiment. IV. Zooplankton population dynamics and production. Mar. Sci. Communs. 3: 355-394

Blackbourn, D. J. (1974). The feeding biology of tintinnid Protozoa and some other inshore microzooplankton. Ph. D. thesis, Univ. British Columbia, Vancouver

Coats, D. W., Heinbokel, J. F. (1982). A study of reproduction and other life cycle phenomena in planktonic protists using an acridine orange fluorescence technique. Mar. Biol. 67: 71-79

Cosper, T. C. (1972). The identification of tintinnids (Protozoa: Ciliata: Tintinnida) of the St. Andrews Bay system, Florida. Bull. mar. Sci. 22: 391-418

Davis, C. D. (1978). Variations of the lorica in the genus Parafavella (Protozoa: Tintinnida) in northern Norway waters. Can J. Zool. 56: 1822-1827

Durbin, A. G., Durbin, E. G. (1981). Standing stock and estimated production rates of phytoplankton and zooplankton in Narragansett Bay, Rhode Island. Estuaries 4: $24-41$

Durbin, E. G., Krawiec, R. W., Smayda, T. J. (1975). Seasonal studies on the relative importance of different size fractions of phytoplankton in Narragansett Bay (USA). Mar. Biol. 32: 271-287

Edmondson, W. T. (1974). Secondary production. Mitt. int. Ver. Limnol. 20: 229-272

Fenchel, T. (1974). Intrinsic rate of natural increase: the relationship with body size. Oecologia (Berl.): 14: 317-326
Finlay, B. J. (1977). The dependence of reproductive rate on cell size and temperature in freshwater ciliated Protozoa. Oecologia (Berl.) 30: 75-81

Furnas, M. J. (1982). Growth rates of summer nanoplankton $(<10 \mu \mathrm{m})$ populations in lower Narragansett Bay, Rhode Island, USA. Mar. Biol. 70: 63-72

Gold, K., Morales, E. A. (1976). Studies on the sizes, shapes, and the development of the lorica of agglutinated Tintinnida. Biol. Bull. mar. biol. Lab., Woods Hole 150: 377-392

Hargraves, P. E. (1981). Seasonal variations in tintinnids (Ciliophora: Oligotrichida) in Narragansett Bay, Rhode Island, USA. J. Plankton Res. 3: 81-91

Heinbokel, J. F. (1987a). Studies on the functional role of tintinnids in the Southern California Bight. I. Grazing and growth rates in laboratory cultures. Mar. Biol. 47: 177-189

Heinbokel, J. F. (1987b). Studies on the functional role of tintinnids in the Southern California Bight. II. Grazing rates of field populations. Mar. Biol. 47: 191-197

Hollibaugh, J. T., Fuhrman, J. A., Azam, F. (1980). Radioactively labelling of natural bacterioplankton for use in trophic studies. Limnol. Oceanogr. 25: 172-181

Holm-Hansen, O., Lorenzen, C. J., Holmes, R. W., Strickland, J. D. H. (1965). Fluorometric determination of chlorophyll. J. Cons. 25: $115-128$

Kofoid, C. A., Campbell, A. S. (1929). A conspectus of the marine and freshwater Ciliata belonging to the suborder Tintinnoinea, with descriptions of new species, principally from the Agassiz Expedition to the eastern tropical Pacific, 1904-1905. Univ. Calif., Berkeley, Publ. Zool. 34: $1-403$

Kofoid, C. A., Campbell, A. S. (1939). Reports on the scientific results of the expedition to the eastern tropical Pacific, in charge of A. Agassiz, by the U.S. Fish Commission steamer 'Albatross' from October 1904 to March 1905, Lieut.-Commander L. N. Garrett, USN, commanding. XXXVII. The Ciliata: the Tintinnoinea. Bull. Mus. comp. Zool. Harv. 84: 1-473

Laws, E. A., Archie, J. W. (1981). Appropriate use of regression analyses in marine biology. Mar. Biol. 65: 13-16

Parsons, T. R., Takahashi, M. (1973). Biological oceanographic processes. Pergammon Press, New York

Ricker, W. E. (1973). Linear regressions in fishery research. J. Fish. Res. Bd Can. 30: 409-434

Robertson, J. R. (1983). Predation by estuarine zooplankton on tintinnid ciliates. Estuar. coast. Shelf Sci. 16: 27-36

Sharp, J. H. (1974). Improved analysis for 'particulate' organic carbon and nitrogen from seawater. Limnol. Oceanogr. 19: 984-989

Snedecor, G. W., Cochran, W. G. (1967). Statistical methods Iowa State Univ. Press, Ames

Spittler, P. (1973). Feeding experiments with tintinnids. Oikos 15 (S) : 128-132

Stoecker, D., Davis, L. H., Provan, A. (1983). Growth of Favella sp. (Ciliata: Tintinnina) and other microzooplankters in cages incubated in situ and comparison to growth in vitro. Mar. Biol. 75: 293-302

Stoecker, D. K., Govoni, J. J. (1984). Food selection by young larval Gulf menhaden (Brevoortia patronus). Mar. Biol. 80: 299-306

Taniguchi, A., Kawakami, R. (1983). Growth rates of ciliates Eutintinnus lususundae and Favella taraikaensis observed in the laboratory culture experiments. Bull. Plank. Soc. Jap. 30: 33-40

Tremblay, M. J., Roff, J. C. (1983). Production estimates for Scotian Shelf copepods based on mass P/B ratios. Can. J. Fish. Aquat. Sci. 40: 749-753

Uye, S., Iwai, Y., Kasahara, S. (1983). Growth and production 
of the inshore marine copepod Pseudodiaptomus marinus in the central part of the Inland Sea of Japan. Mar. Biol. 73: $91-98$

Vargo, G. A., Hargraves, P. E., Johnson, P. (1975). Scanning electron microscopy of dialysis tubes incubated in flowing seawater. Mar. Biol. 31: 113-120

Verity, P. G. (1984). The physiology and ecology of tintinnids in Narragansett Bay, Rhode Island. Ph. D. thesis, Univ. Rhode Island, Kingston

Verity, P. G. (1985). Grazing, respiration, excretion, and growth rates of tintinnids. Limnol. Oceanogr. 30: $1268-1282$
Verity, P. G. (1986). Grazing of phototrophic nanoplankton by microzooplankton in Narragansett Bay. Mar. Ecol. Prog. Ser. 29: 105-115

Verity, P. G., Langdon, C. (1984). Relationships between lorica volume, carbon, nitrogen, and ATP content of tintinnids in Narragansett Bay. J. Plankton Res. 6: 859-868

Verity, P. G., Stoecker, D. (1982). Effects of Olisthodiscus luteus on the growth and abundance of tintinnids. Mar. Biol. 72: 79-87

Verity, P. G., Villareal, T. A. (1985). The relative food value of diatoms, dinoflagellates, flagellates, and cyanobacteria for tintinnid ciliates. Arch. Protistenk. (in press)

This paper was submitted to the editor; it was accepted for printing on December 17, 1985 